\title{
Foreignization and Domestication Strategies in Cultural Term Translation of Tourism Brochures
}

\author{
Choirul Fuadi \\ Choirulfuadi78@gmail.com \\ State University of Yogyakarta \\ Jl. Colombo No. 1, Depok, Sleman, Daerah Istimewa Yogyakarta, Indonesia
}

Received: July 24, 2016; Accepted: August 29, 2016; Published: September 27, 2016

\begin{abstract}
In translating brochure, a translator has to make a decision on the basis of the message and purpose. The translator is faced by two strategies of translation foreignization and domestication. The purpose of the study is to examine how the interrelationship between cultural term translation and foreignization or domestication strategy in the cultural term translation of tourism brochure from Indonesian into English. This study used qualitative descriptive with discourse analysis strategy. The note-taking technique is used to identify and classify the data. The objects of the study are tourism brochures from Province of Special Region of Yogyakarta and Central Java in 2015. The findings show that the translation strategies used depend on the translation process. When the cultural terms are familiar, translator tends to use domestication strategy and consider the target text. Translator chooses domestication strategy because try to make tourist understand the text and produce communicative and natural translation. On the other hand, when cultural terms are foreign, translator using foreignization strategy and consider source text. Using foreignization strategy, translator tends to introduce traditional cultural term.
\end{abstract}

Keywords: discourse analysis, foreignization, domestication, cultural category, tourism brochure

How to cite this paper: Fuadi, C. (2016). Foreignization and Domestication Strategies in Cultural Term Translation of Tourism Brochures. Journal on English as a Foreign Language, 6(2), 171-188. 
The tourism industry in Indonesia is increasing; it is looked by the increasing number of tourists who visited Indonesia. Government through program Visit Indonesia massively promotes the tourism destination of Indonesia via banner, brochure, social media, advertising, etc. The brochure is one of the media to promote and inform about tourism destination in a region. The objective of tourist brochures is to attract visitors to the region and support the livelihood of the local people (Luonua, 2013, p. 1).

Many brochures in Indonesia are written in Bahasa Indonesia, but international tourists need to understand the text. It is because International tourists from foreign countries may have little knowledge and experience about local culture. Consequently, translation bureaus and translators are very important and become a national need and a must in daily life, especially in translation for a brochure from Indonesia into International language such English.

Many aspects should be considered in translating text, one of which is the cultural term. Translation and culture are a concept related each other. A translator needs to have a good knowledge about source and target text, as stated by Newmark $(1988$, p. 5) that texts always engage the person, universal and culture.

Newmark (1988, p. 95) categorize cultural category into five categories. They are 1) Ecology: fauna, flora, and geographical features, 2) Material culture: clothes, food, houses/city, transports, and traditional weapons, 3) Social culture: work, leisure, names and terms of address, and kinship. 4) Social Organization: social organization, social administration, religion, artistic things and craft, 5) Habits and gesture. With these in mind, the translator might consider those categories in their source text.

A translator in the translation process is facing a challenge. Nida cited by Sudana, Suyasa, and Marsakawati (2014, p. 437) stated that there are four challenges in the translation process. The first challenge is language. The second challenge is social culture. The third challenge is a religious term. The last challenge is material culture. In summary, the challenge in translation process is language and culture.

Regarding the challenges, translator not only needs to have a background of language but also culture both source culture and the target culture. The knowledge of language and culture is required to produce a good translation in the meaning and style. As stated by Nida and Taber (1969, p. 12) define translation as "translating consist of reproducing in the receptor language the closest natural equivalent of the source-language message, first in the meaning and secondly in the term of style. A translator needs to choose the closest term in the translation process. 
In translating text, a translator has to make a decision on the basis of the message and purpose. A translator is also faced by two strategies of translation; foreignization and domestication. Each of strategy will give a different output of translation. As Tanjung $(2015$, p. 12) stated that foreignization consider the source text, while domestication considers the target text.

In examining cultural translation, Farahani (2013, p. 112) mentioned that discourse analysis is a field of study which tries to investigate the relationship between language and context. He also mentioned that discourse analysis connected to other disciplines. It is also supported by Purbani $(2005$, p. 2) in the seminar about discourse analysis who stated that discourse analysis is broadly used to examine many disciplines, especially socio-culture. Discourse analysis can be used to analyze of history, politics, social, culture, and psychology.

Previously, Farahani (2013, p. 112) mentioned that one of the most interesting fields of study which have been recently affected by Discourse Analysis is a newly -born trend called Translation studies. It aims at analyzing these concepts and terms in relation to translation studies. The concepts are Halliday's systematic functional grammar, Julian House model of translation quality assessment and Katherine Reis's text typology in translation.

Farahani (2013, p. 115) made the conclusion that translation is more than the mere replacement of the source text materials into the target text. He assumed that there are so many other different factors. As mentioned by Farahani (2013, p. 112) previously, discourse analysis has, to a great extent, contributed to the notion of translation. Farahani (2013, p. 113) has looked at translation from discourse analysis point of view and believes discourse as a socio-cultural environment in which communication is taken place. Then, the job of the translator is to identify the socio-cultural environment of the source text and transfer the message (Farahani, 2013, p. 115).

The second study about domestication and foreignization was done by Shokri and Ketabi (2015). The study sought to find which of the strategies was used more frequently in the English translation of the Persian literary masterpiece ShazdehEhtejab, translated by Buchan in 2005. In the beginning, they took thirty-four culture-specific items which were extracted from the text and then analyzed according to Newmark's (1988) categorization of culturespecific items. Then, those items were examined according to Aixela's (1996) model of translating culture-specific items, which were divided all the strategies into two broader categories of Domestication and Foreignization. They tried to find the most frequent strategy.

The result showed that Domestication with eighty-two percent was more frequent, which stood as the main approach of the translator. Moreover, as a subcategory of Domestication, synonymy was the most frequent strategy with 
thirty-nine percent. They assumed that by applying domesticated equivalents, the translator hid the local color of the source text.

Rise (2016, p. 392) stated both foreignization and domestication are important in translation process especially in maintenance the culture of a nation. In the conclusion, she made two conclusions; first, in the transferred meaning and relevant culture term in the translation process, the translator needs to consider domestication strategy. Second, in the context of crosscultural understanding, translator considers to introducing the foreign culture, in other word foreignization strategy is required by the translator.

She gives a suggestion, both strategies will influence to translation output including equivalency, readability, and acceptability. Regarding the strategy, a translator needs to consider both strategies and understanding the situation. The last, choose the closest term or low risk is the best way in the translation process.

Moreover, Machali (2012) concluded that the translation strategies employed by the translator reflect his/her interpretation that dictates the translation process. When the cultural elements are considered as foreign the translator tends to use the domestication strategy. On the other hand, when the 'foreign' element is related to a known genre such as the Ramayana, the translator has chosen to use the foreignization strategy. Both strategies reflect the translator's power or mandate to interpret the original text and realize it in the translation; this is a power that may have been granted to him/her by the publisher.

Different with the previous studies, this paper aims to examine the interrelationship between the translation of cultural terms and foreignization or domestication strategy in the translation of tourism brochures from Indonesian into English in the Province of Special Region of Yogyakarta and Central Java 2015. The present study has a problem statement, "What is the translator strategy in translating cultural terms from Indonesian into English in Tourism Brochures?" Therefore, the purpose of the study is to examine how the interrelationship between cultural term translation and foreignization or domestication strategy in the cultural term translation of tourism brochure from Indonesian into English. The tourism brochures are from Province of Special Region of Yogyakarta (Yogyakarta Tourism Authority, 2015) and from Central Java (Jawa Tengah Provincial Culture and Tourism Office, 2015).

As stated in Oxford dictionary, the brochure is a booklet containing information or advertisement. The example of the brochure is tourism brochure. The brochure has functioned as information, identification and advertisement. A particularly interesting form of print media is tourism brochure, typically a small-sized leaflet containing information on the city and its parts (Hiipala, 
2007, p. 1-2). In the tourism sector, one of the original functions of tourism brochure is providing service information (Luo \& Huang, 2015, p. 203).

Hiipala (2007, p. 2) added that the purpose of the tourism brochure is to portray the city in a positive light as an attractive destination for tourists. Luonua (2013, p. 1) stated that the objective of tourism brochures is to attract visitors to the region and support the livelihood of local people. Then tourism brochures are produced to induce travelers to choose one destination (Edelheim, 2007, p. 7).

As the provinces that take the source of income from tourism sector to accelerate the development, the province of Special Region of Yogyakarta and Central Java issued and published tourism brochures in 2015. Those brochures have similar characteristics which contain information of touristic spots in each province.

The tourism brochure of Yogyakarta is published by Yogyakarta Tourism Authority. The brochure can be accessed on www.visitingjogja.go.id. The brochure of Yogyakarta consists of landscape, such as mountain, beach, and other aspects such as a monument, museum, building, temple, nature, and culinary.

The tourism brochure of Central Java is published by Jawa Tengah Provincial Culture and Tourism Office. The brochure can be accessed on www.central-java-tourism.com. The brochure of Central Java consists of landscape, such as a museum, building, temple, nature, and culinary.

Many famous scholars have discussed and developed discourse analysis, one of them is Fairclough. Fairclough's ideology cited by Purwanti and Mujiyanto (2015, p. 65) in discourse analysis is encoded in the lexical, grammatical and textual items. Lexical item is a word or a sequence of words that acts as a unit of meaning. It can be generally understood to convey a single meaning but is not limited to single words.

As stated previously, Farahani (2013, p. 112) mentioned that discourse analysis is a field of study which tries to investigate the relationship between language and context; it is connected to other disciplines, especially socioculture. Discourse analysis can be used for analysis in other disciplines of history, politic, social, culture, and psychology (Purbani, 2005, p. 2). Farahani (2013, p. 115) made the conclusion that translation is more than the mere replacement of the ST materials into the TT. Moreover, Farahani (2005) assumed that discourse analysis also contributed to the notion of translation. Then, the job of the translator is to identify the socio-cultural environment of the Source Text and transfer the message. Discussing discourse and culture, in the analysis of text, a researcher or writer considers that the text has a context, a process of production or text production, the process of interpretation or text consumption 
and also socio-cultural practice. And then, in the analysis of text, discourse and culture can be assessed on translation.

Foreignization and domestication concepts were firstly discussed by Schleiermacher in the early 19th century (Mansour, 2014, p. 25). The terms foreignization and domestication were coined by Venuti cited by Munday, 2008, p. 145), an American Translation theorist. Purwanti and Mujiyanto (2015, p. 65) stated that in translation practice, domestication and foreignization are very important concepts in deciding a translator's ideology to the linguistic and cultural differences of the source text. She also mentioned that foreignization aims for cultural transfer, whereas domestication tends to be the very reverse of this transference. It is supported by Yang (2010, p. 77) that domestication and foreignization are two basic translation strategies which provide both linguistic and cultural guidance for translators in rendering culture-specific source texts into parallel target texts.

Mansour (2014, p. 25-26) stated that foreignization chooses a foreign text and developing a translation method along lines which are excluded by dominant cultural values in the target language, while domestication aims to reduce the impact of foreignness in the target text due to ethnocentric trends that stimulate the translator to elevate his own cultural references and keep them intact from other alien ones. It was also mentioned by Tanjung (2015, p. 12) that foreignization considers the source text, while domestication considers the target text.

Another definition is also stated by Purwanti and Mujiyanto (2015, p. 64). In domestication translation, a translator attempts to produce a target language translation as naturally as possible. On the other hand, in foreignization translation, a translator attempts to take the target language readers to the foreign culture and make them feel about the linguistic and cultural differences. The target language readers will recognize that they are not reading an original text.

Mujiyanto (2015, p. 177) stated that domestication is a transparent and fluent foreign text and is created for the convenience of the target-text readers. This style is adopted in order to minimize the strangeness of the foreign text for target language readers. He assumed that by this strategy making the text recognizable and familiar and thus bringing the foreign culture closer to that of the readers.

As opposed to domestication strategy, Mujiyanto (2015, p. 178) stated foreignization strategy refers to the type of translation in which a target text deliberately breaks target conventions by retaining - something of the foreignness of the original. He assumed that foreignization strategy means to take the reader to the foreign culture and to make him or she feel the linguistic 
and cultural differences. In other word, the foreignization strategy is recognized as loan word (Baker, 1992) and borrowing (Vinay \& Darbelnet cited by Venuti, 2000).

Machali (2012, p. 2) gives an opinion to the notion of foreignization and domestication. She stated that the main strategies that have been proposed and debated over are: domestication and foreignization. She also stated other terms of domestication and foreignization that have been used instead of these, for example 'acculturation' instead of domestication. For purposes of contrast, the terms 'domestication' is used here rather than acculturation, for purposes of contrasting it with foreignization.

Referring to the advantage and disadvantage of domestication and foreignization, Risna (2016, p. 388-389) stated that in advantage perspective; domestication strategy have advantages as follow; 1) reader of target text easy to understand the translated text, 2) the translated text is natural and communicative, 3) any chance of assimilation. Meanwhile, foreignization strategy have advantages as follows; 1) reader of target text understand the culture of the source text, 2) translated text feel seems like the culture of the source text, 3) any chance of intercultural learning.

On the contrary, disadvantages perspective; domestication has disadvantages; 1) faded of source text cultural term, 2) reader might not interpret the text because the translator has interpreted the cultural term, 3) reader does not get cultural term of source text. Meanwhile, foreignization strategy has disadvantage as follows; 1 ) reader might feel foreign through the cultural term, 2) text of source text often complex and not natural in the translated text, 3) negative aspects from source text might influence the reader.

According to domestication and foreignization, Toury cited by Mansour (2014, p. 29) confirms that translation is a kind of activity which involves at least two things, cultural traditions, and languages. And then, translation can be defined as translating more than words and terms. It is also translating culture, lifestyle, and life.

A cultural term is usually marked by special characteristics. Every language in the world has its own words, phrases, or expressions that marked by special characteristics. Culture is also as complex things, including religion system and politic, custom, language, tool, cloth, building and artistic things.

One aspect of culture is that language is part of culture (Risna, 2016, p. 382 ). In the point, translation is relating with language and culture. Sutrisno (2005, p. 133) stated that language and culture are relating and there is interrelationship between language and culture. He also defines language as an expression of culture and person of a native speaker, and then automatically language will influence the speaker. 
Discussing nature, culture, and language, these terms are relating each other. One way thinking about culture is to contrast it with nature. Kramsch $(1998$, p. 4) stated that nature refers to what is born and grows organically (from Latin nascere : to be born). Meanwhile, culture refers to what has been grown and groomed (from the Latin colere: to cultivate). Kramsch (1998) added that language and culture impose on nature correspond to the various form of socialization or acculturation. The use of written language is also shaped and socialized through culture.

There are various definitions of culture. Kamus Besar Bahasa Indonesia (Indonesian dictionary) defines culture as follow; 1) though; 2) custom, 3) something relating to developed culture (civilized); 4) something has become a habit. Meanwhile, oxford dictionary defines culture as customs, beliefs, art, way of life, etc of particular country or group. Newmark (1998, p. 94) defines culture as the way of life and its manifestations that are peculiar to a community that uses a particular language as its means of expression.

More specifically, Newmark (1998, p. 94) distinguishes 'cultural' from 'universal' and 'personal language'. For example; 'Die', 'live, 'star', 'swim' and even almost virtually ubiquitous artifacts like 'mirror' and 'table' are universals. In this case, usually, there is no translation problem there. In other words, 'Monsoon', 'steppe', 'dacha', 'tagliatelle' are cultural words - there will be a translation problem unless there is cultural overlap between the source and the target language (and its readership). Newmark added the most specific a language becomes for natural phenomena (e.g., flora and fauna) the more it becomes embedded in cultural features and therefore creates translation problems. Which is worrying, since it is notorious that the translation of the most general words (particularly of morals and feelings) - love, temperance, temper right, wrong - is usually harder than that of specific words.

Additionally, Newmark (1988, p. 95) discusses the translation of foreign cultural words in the narrow sense. He classifies culture-specific terms into five categories. They are; (1) Ecology: fauna, flora, and geographical features, (2) Material culture: clothes, food, houses/city, transports, and traditional weapons, (3) Social culture: work, leisure, names and terms of address, and kinship, (4) Social Organization: social organization, social administration, religion, artistic things and craft, and (5) Habits and Gesture.

\section{METHOD}

This research is qualitative descriptive research. The documentary study guide was used as the instrument. Note-taking was used to identify and classify the data, the cultural terms so that it was much easier to formulate the analysis. Discourse analysis was used to analyze the data. 
The cultural terms in this study include words, phrases, and clauses contained in Tourism Brochures. Newmark's (1998, p. 95) culture-specific terms categorization are used to determine the cultural terms. The object is tourism brochures from provinces of a special region of Yogyakarta and Central Java in 2015. The brochures were issued and published by the government of Yogyakarta and Central Java. The brochures have two versions, Indonesian as source text and English as target text. The brochures contain several tourism spots in both provinces.

\section{FINDINGS}

There were 106 data of cultural terms extracted from the tourism brochures. The data were categorized according to Newmark's (1998) categorization. The findings are as follows.

Ecology: Fauna (6 data), Flora (4), and geographical features (15)

Table 1. Ecology Category

\begin{tabular}{|c|c|c|c|}
\hline No & Category & Indonesian & English \\
\hline 1 & \multirow{6}{*}{ Fauna } & Burung berkicau & Birds chirping \\
\hline 2 & & Kuda & Horses \\
\hline 3 & & Ikan hias & Ornamental fish \\
\hline 4 & & Biota laut & Marine life \\
\hline 5 & & Ikan karang berwarna & Colorful reef fish \\
\hline 6 & & Kera & Primates \\
\hline 7 & \multirow{4}{*}{ Flora } & Cemara & Pine trees \\
\hline 8 & & Rumput laut & Seaweed \\
\hline 9 & & Terumbu karang & Coral reefs \\
\hline 10 & & Pinus & Pine \\
\hline 11 & \multirow{14}{*}{$\begin{array}{l}\text { Geographical } \\
\text { feature }\end{array}$} & Kaliurang & Kaliurang \\
\hline 12 & & GunungMerapi & Mount Merapi \\
\hline 13 & & Air terjun sri gethuk & Sri Gethuk Waterfall \\
\hline 14 & & Perbukitan menorah & Menorah hills \\
\hline 15 & & Waduk sermo & Sermo reservoir \\
\hline 16 & & Taman Nasional Karimunjawa & $\begin{array}{l}\text { Karimunjawa National } \\
\text { Park }\end{array}$ \\
\hline 17 & & Dataran tinggi dieng & Diengplateu \\
\hline 18 & & Telagawarna & Warna lake \\
\hline 19 & & Telaga Pengilon & Pengilon lake \\
\hline 20 & & Sumur Jalatunda & Jalatunda Well \\
\hline 21 & & Telaga menjer & Menjer lake \\
\hline 22 & & Kawah candradimuka & Candradimuka crater \\
\hline 23 & & Kawah sikidang & Sikidang crater \\
\hline 24 & & Rawa pening & Pening swamp \\
\hline
\end{tabular}

Journal on English as a Foreign Language, 6(2), 171-188

Copyright (C) 2016 by JEFL, p-ISSN 2088-1657; e-ISSN 2502-6615 
Material culture: clothes (1 datum), food (8 data), houses/city (20 data), transports ( 7 data), and traditional weapons (1 datum).

Table 2. Material Culture Category

\begin{tabular}{|c|c|c|c|}
\hline No & Category & Indonesian & English \\
\hline 25 & Clothes & Batik & Batik \\
\hline 26 & \multirow{8}{*}{ Food } & Gudeg & Gudeg \\
\hline 27 & & Seafood & Sea food \\
\hline 28 & & Soto Kudus & Soto Kudus \\
\hline 29 & & Tahu Kupat & Tahu Kupat \\
\hline 30 & & Nasi Liwet & Nasi Liwet \\
\hline 31 & & Sate Ambal & Ambal satay \\
\hline 32 & & Lumpia & Lumpia \\
\hline 33 & & Mie Ongklok & Ongklok Noodles \\
\hline 34 & \multirow{20}{*}{ Houses/city } & Kraton & Sultan's Palace \\
\hline 35 & & Masjid Gedhe Kauman & $\begin{array}{l}\text { Kauman Grand Mosque } \\
\text { (Masjid Gedhe Kauman) }\end{array}$ \\
\hline 36 & & Taman sari & Water Castle (Taman Sari) \\
\hline 37 & & Pesanggrahan & Resting Area \\
\hline 38 & & Benteng Pertahanan & Defense Area \\
\hline 39 & & Titik Nol & $\begin{array}{l}\text { Nol Kilometer (zero } \\
\text { kilometers) }\end{array}$ \\
\hline 40 & & Puro Pakualaman & Pakualaman \\
\hline 41 & & Candi & Temple \\
\hline 42 & & Gapura & Gate \\
\hline 43 & & Paseban & Paseban (hall) \\
\hline 44 & & Pendapa & Gazebo \\
\hline 45 & & Tembi Rumah Budaya & Tembi Rumah Budaya \\
\hline 46 & & Tempat ibadah & Places of worship \\
\hline 47 & & Gardu Pandang & Guard House \\
\hline 48 & & Lounge & Lounges \\
\hline 49 & & Lawang sewu & Lawang sewu \\
\hline 50 & & $\begin{array}{l}\text { Masjid dan menara } \\
\text { kudus }\end{array}$ & Kudus mosque \\
\hline 51 & & Masjid agung demak & Demak great mosque \\
\hline 52 & & Gereja Blenduk & Blenduk Church \\
\hline 53 & & Klenteng Sam poo Kong & $\begin{array}{l}\text { Sam Poo Kong Chinese } \\
\text { temple }\end{array}$ \\
\hline 54 & \multirow{5}{*}{ Transportation } & Jeep & Jeep \\
\hline 55 & & Pesawat & Planes \\
\hline 56 & & Kereta Kuda & Carriage Horses \\
\hline 57 & & ATV & ATV \\
\hline 58 & & Kereta kencana & Royal carriage \\
\hline
\end{tabular}

Journal on English as a Foreign Language, 6(2), 171-188

Copyright @ 2016 by JEFL, p-ISSN 2088-1657; e-ISSN 2502-6615 


\begin{tabular}{llll}
$\frac{59}{60}$ & & Kendaraan umum & Public transportation \\
\cline { 3 - 4 } \cline { 3 - 4 } & & Kendaraan pribadi & Private transportation \\
\hline 61 & Traditional weapon & Keris & Keris \\
\hline
\end{tabular}

Social culture: work ( 3 data), leisure (10 data), names and terms of address (11 data), and kinship (3 data).

Table 3. Social Culture Category

\begin{tabular}{|c|c|c|c|}
\hline No & Category & Indonesian & English \\
\hline 62 & \multirow{3}{*}{ Work } & Seniman Jalanan & Street Artist \\
\hline 63 & & Pelukis Impresionis & Impressionist painters \\
\hline 64 & & Nelayan & Fisherman \\
\hline 65 & \multirow{10}{*}{ Leisure } & Menyelam & Diving \\
\hline 66 & & Snorkeling & Snorkeling \\
\hline 67 & & Trekking mangrove & Trekking \\
\hline 68 & & Canoeing & Canoeing \\
\hline 69 & & Memancing & Fishing \\
\hline 70 & & Berlayar & Sailing \\
\hline 71 & & Melihat penangkaran hiu & Seeing shark breeding \\
\hline 72 & & $\begin{array}{l}\text { Menyelami kehidupan } \\
\text { kampong nelayan bugis }\end{array}$ & $\begin{array}{l}\text { Immersing yourself in Bugis } \\
\text { fisherman's life }\end{array}$ \\
\hline 73 & & Menyusuri Gua & Caving \\
\hline 74 & & Mendaki Gunung & Hiking \\
\hline 75 & \multirow{11}{*}{$\begin{array}{c}\text { Names and terms } \\
\text { of address }\end{array}$} & Cave tubing & Cave tubing \\
\hline 76 & & Caving (Susur gua) & Caving activity (fringe cave) \\
\hline 77 & & $\begin{array}{l}\text { Body Rafting (olahraga arus } \\
\text { deras) }\end{array}$ & $\begin{array}{l}\text { Body rafting (sport swift } \\
\text { current) }\end{array}$ \\
\hline 78 & & Arung Jeram (rafting) & Rafting \\
\hline 79 & & Geologika & Geological \\
\hline 80 & & Biologika & Biological \\
\hline 81 & & Etnografika & Ethnographical \\
\hline 82 & & Koleksiar keologika & Archaeological \\
\hline 83 & & Historika & Historical \\
\hline 84 & & Numistika & Numimastical \\
\hline 85 & & Keramologika & Keramological \\
\hline 86 & \multirow{3}{*}{ Kinship } & Bangsawan Dinasti Mataram & Mataram dynasty nobles \\
\hline 87 & & Raja-raja & Kings \\
\hline 88 & & Permaisuri & Queens \\
\hline
\end{tabular}


Social Organization: social organization, social administration, religion (6 data), artistic things and craft (11 data),

Table 4. Social Organization

\begin{tabular}{|c|c|c|c|}
\hline No & Category & Indonesian & English \\
\hline 89 & \multirow{6}{*}{ Religion } & Hindu & Hindu \\
\hline 90 & & Islam & Islamic \\
\hline 91 & & Iman & Faith \\
\hline 92 & & Islam & Muslims \\
\hline 93 & & Ikhsan & Good deeds \\
\hline 94 & & Budha & Buddha \\
\hline 95 & \multirow{10}{*}{$\begin{array}{l}\text { Artistic things and } \\
\text { craft. }\end{array}$} & Kerajinan Perak & Silver Handicraft \\
\hline 96 & & Gerabah & Pottery \\
\hline 97 & & Guci & Jars \\
\hline 98 & & Pot & Pot \\
\hline 99 & & Souvenir & Souvenir \\
\hline 100 & & Pigura & Frames \\
\hline 101 & & Meja & Tables \\
\hline 102 & & Kursi & Chair \\
\hline 103 & & Artefak & Artifacts \\
\hline 104 & & Relief & Relief \\
\hline
\end{tabular}

\section{Habits (1 data) and Gesture}

Table 5. Habit and Gesture Category

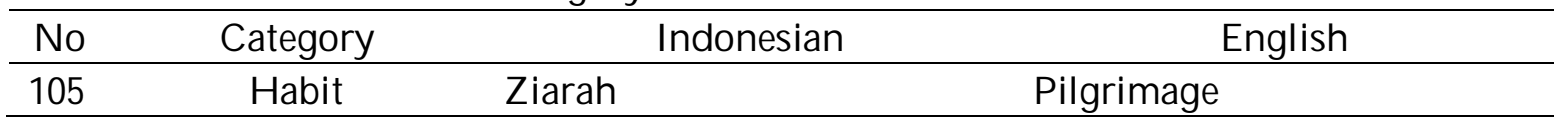

\section{DISCUSSION}

In the ecology category, mostly the translator considers to target text or using domestication strategy in translating the text. The translator tends to use domestication because the source text is generally familiar and considering there are no different in the target text. For example, in the fauna sub-category, the word "Kuda" is translated into "horse". The words "kuda" and "horse" are familiar both in the source and target texts. "Kuda or horse" refers to an animal that has four legs and people ride on or use for pulling carts.

In the flora sub-category, the word "pinus" is translated into "pine". Both "pine and pinus" are familiar in the source and target texts as "tree". Pinus is a plant that is planted in mountainside or slope of the hill; it also has leaves like needles. Another example is word "terumbu karang" that is translated into "coral reef". The coral reef is a substance formed in the sea. 
The translator might consider that the tourists have been familiar with those words. In this case, the interpretation of cultural term has been conducted by the translator. Based on the advantage of domestication strategy, the reader will feel natural and communicative of translated text.

In the geographical sub-category, there are several names of place with a geographical feature in the brochures. For example such "Gunung Merapi" translated into "Mount Merapi", "Air Terjun Sri Gethuk" translated into "Sri Gethuk Waterfall," "Telaga Warna" translated into "Warna Lake". The terms of geographical features are familiar for International tourist. Translator considers the target text by applied domestication strategy. In this case, the translator only translated the geographical feature and maintained the name of the place, such in "Gunung Merapi" translated into "Mount Merapi". Mount Merapi is a place of the mount and located in Special Region of Yogyakarta province.

Another example is "Telaga Warna" translated into "Warna Lake". "Warna Lake" is a lake with many story and history. It located in Central Java Province. Warna Lake is also tourism spot in Central Java province. By applying this strategy, translator wants to make natural translation and reader understand well the information of the brochure.

In the material culture category, in the sub-category of clothes and traditional weapon, the translator translated "Batik and Keris" into "Batik and Keris". The words are foreign in the target text. Here, translator considers the sourcing text. Batik is both an art and a craft; in Java, Indonesia, batik is also a part of an ancient tradition. Meanwhile, Keris is a traditional weapon from Indonesia.

In this case, the translator used foreignization strategy or consider to source text. The purpose of the translation process is to introduce "Keris and Batik" as traditional culture of Indonesia. In addition, the translator also wants the reader of translated text to understand the cultural of the source text.

In the sub-category of food, the translator used both domestication and foreignization. The terms of a sub-category of food are familiar for International tourist. Translator considers the target text by applied domestication strategy. In this case, the translator only translated the term of food and maintained the name of food. For example in the term "Mie ongklok" translated into "Ongklok Noodles." "Mie or noodles" is familiar food in many countries as food from wheat and has long shape. And then, Ongklok or Mie ongklok is noodles with cabbage and chutney. It is also traditional food from Wonosobo, Central Java province. In this case, translator tends to introduce Indonesian traditional food.

Meanwhile, in the foreignization strategy, the translator considered the source text by applied borrowing translation technique. For example; translator translated "Soto Kudus" into "Soto Kudus" and "Nasi Liwet" into "Nasi Liwet". 
"Soto Kudus" is a traditional food; soto (soup) from Kudus, Central Java, Indonesia. "Nasi liwet"; is a traditional food from Solo, Indonesia. Nasi liwet is rice with squash, chicken, and some local ingredients. By foreignization strategy, the translator also tends to introduce "Soto Kudus and Nasi Liwet" as traditional food of Indonesia. In addition; foregnization strategy also might make the reader (tourist) learn about Indonesian culture, especially in food.

In the sub-category of houses/city; the translator considers both the target and source text or uses domestication and foreignization strategy. For example; translator translated "Pesanggrahan" into Resting Area. The term "Pesanggrahan", in Indonesian, means a house for rest. And then, the translator use modulation technique in translating cultural term. Modulation technique helps translator in translating the message or meaning. In this term, translator uses domestication strategy in translating. The translator has interpreted the meaning of the cultural term of "pesanggrahan".

Another example is term "Paseban" which is translated into "Paseban", but the translator gave put it in parenthesis "(hall)". "Paseban" or Hall in Indonesian means balai. The translator uses foreignization to introduce a cultural term or intercultural learning by giving parenthesis.

In the sub-category of transportation, the translator considered the target text. For example in the word "kereta kencana", the translator translated it literally into "royal carriage". "Kereta kencana" usually is used by the royal family of the kingdom. The translator tries to make tourist understand about term "kereta kencana" by translated into "royal carriage".

In the category of social category, work, leisure and name and term of address, also kinship, all of these translation cultural terms considered to the target text or domestication strategy. It is because generally, those terms are familiar, such in the term of "Nelayan" which is translated into a fisherman. "Fisherman" means a person who catches fish, as a job or as a sport. The term of work or profession is generally familiar with many countries.

Another example is "memancing" which is translated into fishing. Fishing means sport or job of catching fish. By applied domestication strategy or considered target text, the translator also wants the reader of translated text to understand the cultural of the source text. In addition, the translator also wants to make the translation more natural.

In the social organization, most of the word is familiar. And then, the translator considered doing domestication strategy. Translator considers the target text. Such in the artistic things and craft, the translator translated literally "Kerajinan Perak" into "silver handicraft". "Silver Handicraft" is the artistic thing that made by hand skill and using the silver material. 
Another example; the cultural term "Gerabah" is translated into pottery. "Gerabah" in Indonesian dictionary means kitchen tools (for cooking, etc) made from clay and burned (for example kendi, belanga). Meanwhile, pottery means artistic thing made of baked clay, such pots, dishes, etc. In this term, the translator uses cultural equivalence technique. Translator considers the target text and pottery is generally familiar. By this strategy, translator wants to make tourist understand and produce a natural and communicative translation.

In the religion term, the translator also considers the target text. For example, the term "Iman" translated into faith. In Indonesian dictionary, "Iman" mean trust (religion term), belief in god, prophet, book, etc. Oxford gives a similar definition; faith means strong religious belief, Muslim religion. By using domestication, translator tries to make natural and communicative translation and make tourist understand.

In the habit category, the translator translated the word "ziarah" into "pilgrimage". Pilgrimage is a journey made by pilgrims. The word is a familiar and known genre. Then, the translator considered doing domestication.

\section{CONCLUSION}

Based on the finding and discussion above about cultural terms translation in tourism brochures from Indonesian into English, it is shown that the translation strategies depend on the translation process. When the cultural terms are familiar, translator tends to use domestication strategy and consider the target text. Translator choose domestication strategy because 1) try to make tourist understand the text, 2) produce communicative and natural translation.

On the other hand, when cultural terms are foreign, translator using foreignization strategy and consider source text. Using foreignization strategy, translator tends to introduce traditional cultural term. In this case, translator wants the cultural term of the source text is on translated text. In addition, by using foreignization strategy, the translator also wants the reader to have intercultural learning.

The translator might consider the tourist familiarity in translating cultural terms. In addition, the translator tried to make the tourists understand by translating the meaning by some ways. First, the translator considered the target text. Second, translator generalized the cultural term.

\section{REFERENCES}

Baker, M. (1992). In other word: A coursebook on translation. London: Sage Publication.

Edelheim, J. R. (2007). Hidden messages: A polysemic reading of tourist brochures. Journal of Vacation Marketing, 13(1), 5-17. 
Farahani, M. V. (2013). The role of discourse analysis in translation. International Journal of Applied Linguistics E English Literature, 2(1), 112-116

Hiippala, T. (2007). A multisemiotic analysis of tourist brochures. Master's Thesis. Helsinki: University of Helsinki.

Jawa Tengah Provincial Culture and Tourism Office. (2015). Tourism attraction 2015 and pesona wisata 2015. Retrieved on 8 August 2016 from www.central-java-tourism.com

Kamus Besar Bahasa Indonesia. (2010). KBBI offline versi 1.1. http://ebsoft.web.id.

Kramsch, C. (1998). Language and culture. New York: Oxford University Press.

Luo, J., \& Huang, T. (2015). Genre-based analysis of American tourism brochure. Journal of Social Sciences, 3, 200-208.

Luonua, M. (2013). Transfer of meaning in tourist brochure translations. Pro Gradu Thesis. Oulu: University of Oulu.

Machali, R. (2012). Cases of domestication and foreignization in the translation of Indonesian poetry into English: A preliminary inquiry. Journal of Language and Culture, 3(4), 74-82.

Mansour, M. H. (2014). Domestication and foreignization in translating culturespecific references of an English text into Arabic. International Journal of English Language E Translation Studies, 2(2), 23-36.

Mujiyanto, Y. (2015). The implementation of domestication strategy to maintain Bahasa's role in adopting novel terminologies for the science-tech undertaking. Language Circle Journal of Language and Literature, 9(2), 177183.

Munday, J. (2008). Introducing translation studies. (2 ${ }^{\text {nd }}$ Ed.). London: Routledge.

Newmark, P. (1988). A textbook of translation. Hertfordshire: Prentice hall.

Nida, E., \& Taber, C. (1969). The theory and practice of translation. Hertfordshire: Prentice Hall.

Purbani, W. (2005). Analisis wacana/discourse analysis. Research Workshop in UBAYA, Surabaya on 28 January 2005. Retrieved on 24 October 2016 from http://staff.uny.ac.id/system/files/pengabdian/dr-widyastuti-purbani$\mathrm{ma} /$ discourse-analysis.pdf

Purwanti, S. E. \& Mujiyanto, Y. (2015). The ideology in the Indonesian-toEnglish translation of cultural terms in tour's bumi manusia. English Education Journal, 5(2), 63-69.

Risna, S. (2016). Peran ideologi penerjemahan dalam pemertahanan budaya bangsa. Proceding of National Seminar and Nationality Dialogue, Cultural Science Faculty, Hasanuddin Univeristy (pp. 381-394). 
Shokri, S., \& Ketabi, S. (2015). Translating culture-specific items in shazdeh ehtejab: examining foreignization and domestication. International Journal of Research Studies in Education, 4(3), 3-16.

Sudana, M. D. S., Suyasa, \& Marsakawati, N. P. E. (2014). Analisis penerjemahan istilah budaya pada novel negeri 5 menara ke dalam bahasa inggris: Kajian deskriptif berorientasi teori newmark. Jurnal Ilmu Sosial dan Humaniora, 3(2), 435-445.

Sutrisno, M. (2005). Teori-teori kebudayaan. Yogyakarta: Kanisius.

Tanjung, S. (2015). Penilaian penerjemahan Jerman -Indonesia. Yogyakarta: Kanwa Publisher.

Venuti, L. (2000). The translation studies reader. New York: Routledge.

Yang, W. (2010). Brief study on domestication and foreignization in translation. Journal of Language Teaching and Research, 1(1), 77-80.

Yogyakarta Tourism Authority. (2015). DIY sight seeing guide book and panduan destinasi wisata DIY. Retrieved on 8 August 2016 from www.visitingjogja.go.id.

\section{Author's Brief CV}

Choirul Fuadi is a student of Applied Linguistics, Graduate Program of the State University of Yogyakarta. His concerns are translation studies and language research. 
